\title{
EFEKTIVITAS PENGELOLAAN WAKAF TUNAI DI BADAN WAKAF INDONESIA
}

\section{THE EFFECTIVENESS OF THE MANAGEMENT OF CASH WAQF IN INDONESIAN WAQF INSTITUTION}

\section{W.Lestari ${ }^{1}$ dan R.Thantawi²}

${ }^{1}$ Program Studi Ekonomi Islam Fakultas Ekonomi Islam Universitas Djuanda, Jl. Tol Ciawi No. 1, Kotak Pos 35 Bogor 16720.

2 Program StudiEkonomi Islam Fakultas Ekonomi Islam Universitas Djuanda, Jl. Tol Ciawi No. 1, Kotak Pos 35 Bogor 16720.

\section{ABSTRACT}

This study was conducted to determine how the management of cash waqf in Indonesia Waqf Board and the effectiveness of the management of the cash waqf. The method used in this research is the Importance Performance Analysis (IPA). The research results obtained are managing cash waqf in Indonesia Waqf Board has been carried out effectively with a percentage of 54 percent, but traditionally, the management of cash waqf is only done for the sake of social infrastructures. While the management of such productive investment in the real sector or investment in the financial sector based on Islamic instruments have not been implemented.

Key words: Effectiveness, Management

\begin{abstract}
ABSTRAK
Penelitian ini bertujuan untuk mengetahui pengelolaan wakaf tunai di Badan Wakaf Indonesia dan keefektifan dari pengelolaan wakaf tunai tersebut. Metode yang digunakan dalam penelitian ini adalah Importance Performance Analysis (IPA). Adapun hasil penelitian yang diperoleh adalah pengelolaan wakaf tunai di Badan Wakaf Indonesia telah dilaksanakan secara efektif dengan persentase 54 persen namun secara tradisional, yaitu pengelolaan wakaf tunai hanya dilakukan untuk kepentingan sarana sosial. Sedangkan pengelolaan secara produktif seperti investasi pada sektor riil atau investasi pada sektor financial berdasarkan pada instrumen syariah belum dilaksanakan.
\end{abstract}

Kata kunci: Efektivitas, Pengelolaan.

Lestari, Wiji. 2016. Efektivitas Pengelolaan Wakaf Tunai Di Badan Wakaf Indonesia. Jurnal Syarikah 2 (1): 214-234. 


\section{PENDAHULUAN}

Peradaban Islam yang menyebar semakin luas, menimbulkan adanya kebutuhan-kebutuhan akan sarana peribadatan dan pendidikan yang turut meningkat pula. Kebutuhan sarana tersebut dapat diperoleh dari orang-orang yang memiliki lahan atau bangunan yang tidak digunakan oleh pemiliknya. Kegiatan pengalihan lahan tersebut dapat dikenal sebagai wakaf. Seiring dengan perkembangan zaman, kegiatan perwakafan tersebut telah menjadi budaya masyarakat luas yang diterapkan hingga saat ini (Hidayanto, 2009: 15, Hermawan, 2014: 151).

Indonesia dengan mayoritas penduduk muslim, dalam membangun masjid dihasilkan dari kegiatan perwakafan yang diberikan oleh orang-orang yang memiliki kelebihan harta. Demikian pula pada bentuk perwakafan lain, seperti wakaf lahan atau tanah. Berdasarkan dari Direktorat Pemberdayaan Wakaf Kementerian Agama RI tanggal 14 Maret 2014 total asset wakaf di Indonesia mencapai 4.142.464.287,906 meter persegi. Namun, wakaf tanah tersebut belum sepenuhnya dikelola dengan baik. Hal ini terlihat dengan hanya 288.429 ratus ribu meter saja yang telah tersertifikasi atau telah terdata oleh pemerintah.

Selain wakaf tanah dan bangunan, di Indonesia juga memiliki bentuk wakaf lain yang yaitu wakaf tunai. Wakaf tunai adalah wakaf yang dibayarkan dengan menggunakan sejumlah uang tertentu atau sering disebut sebagai wakaf benda bergerak. Perolehan wakaf tunai dapat diinvestasikan pada sektor-sektor riil atau lembaga-lembaga keuangan yang berprinsip syariah. Dengan demikian hasil dari investasi tersebut dapat disalurkan untuk membiayai bangunan-bangunan dari wakaf benda tidak bergerak, dapat dikembangkan pula sebagai modal usaha bagi masyarakat yang membutuhkan, dan dalam bentuk investasi lainnya yang dapat membantu mensejahterakan perekonomian dan kehidupan masyarakat. (Badan Wakaf Indonesia, 2014).

Dalam Islam, harta tidak boleh beredar hanya diantara orang-orang kaya saja. Sesuai dengan firman Allah pada Al-qur'an surat Al-Hasyr ayat 7 :

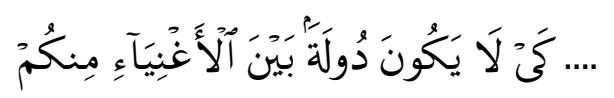

Artinya : "supaya harta itu jangan beredar di antara orang-orang Kaya saja di antara kamu"(QS. AL-hasyr : 7).

Ayat tersebut merupakan motivasi bagi umat muslim untuk melaksanakan wakaf, baik wakaf benda mati maupun benda bergerak. Dengan demikian, wakaf yang terus dilaksanakan oleh masyarakat membuat harta wakaf terkumpul menjadi sangat besar yang dapat dikelola dan diambil manfaatnya untuk kepentingan umat. Namun potensi wakaf tersebut sampai pada saat ini belum dikembangkan dengan maksimal oleh pemerintah karena kendala-kendala tertentu. Sehingga belum memberikan manfaat yang signifikan, baik secara perekonomian maupun dalam membantu kehidupan masyarakat.

\section{MATERI DAN METODE}

Jenis penelitian yang digunakan dalam penelitian ini adalah deskriptif kuantitatif. Deskriptif kuantitatif merupakan metode yang menjabarkan suatu penelitian secara realistis, obyektif, dan dapat diukur melalui alat-alat analisis statistik (Sugiyono, 2012: 11). Dalam penelitian ini akan menjabarkan mengenai efektivitas pengelolaan wakaf tunai yang terdapat di Badan Wakaf Indonesia, sehingga akan 
diketahui tingkat keefektifan pengelolaan wakaf secara obyektif.

Dalam penelitian ini terdapat tiga variabel yang akan dianalisis, yaitu profesionalisme nazhir (X1), program terlaksana secara optimal (X2), dan adanya keuntungan investasi wakaf tunai (X3). Ketiga variabel tersebut akan dianalisis melalui beberapa tahap untuk mengetahui tentang keefektivan pengelolaan wakaf tunai di Badan Wakaf Indonesia.

Populasi adalah seluruh elemen, anggota atau unsur-unsur yang menjadi pengamatan peneliti (Juliandi, 2014: 51). Dalam penelitian ini, populasi yang ditentukan adalah beberapa Lembaga Keuangan Syariah Penerima Wakaf Uang (LKS-PWU). Sampel adalah menentukan jumlah sampel yang akan diteliti dengan menggunakan metode-metode tertentu. Adapun dalam pendapat lain, sampel diartikan sebagai bagian tertentu yang telah dipilih untuk dianalisis dalam sebuah penelitian. Dengan demikian, dari kedua pendapat tersebut, dalam penelitian ini dipilih Badan Wakaf Indonesia sebagai sampel. Teknik pemilihan responden tersebut didasarkan pada metode random sampling (Umar, 2003: 248 dan Sugiyono, 2012: 120).

Random sampling adalah penentuan sampel dengan cara memilih responden secara acak, karena populasi bersifat homogen. Dengan demikian, untuk memperoleh data yang akan diteliti pada Badan Wakaf Indonesia, peneliti menentukan secara acak dari seluruh karyawan yang terdapat di Badan Wakaf Indonesia yang bekerja dalam bidang pengelolaan wakaf tunai (Juliandi dkk, 2014 : 53).

Berdasarkan obyek yang telah ditentukan peneliti untuk dianalisis, maka dalam hal ini peneliti membutuhkan sumber data yang akurat guna membantu terlaksananya penelitian secara efisien. Sumber data yang dimaksud dalam hal ini terbagi menjadi dua bagian, yaitu:

1. Sumber Primer

Sumber primer adalah data yang dapat diperoleh secara langsung dari sumber yang bersangkutan. Dalam hal ini, peneliti dapat memperoleh data secara langsung dari tempat dilaksanakannya penelitian. Data dapat berupa wawancara dan kuesioner yang diberikan kepada pihak Badan Wakaf Indonesia.

2. Sumber Sekunder

Sumber sekunder adalah data yang diperoleh dari hasil olahan data primer. Data sekunder berfungsi sebagai pendukung dari data primer. Dalam hal ini penulis akan melakukan pengolahan data dari hasil wawancara dan kuesioner yang telah dilakukan secara tertulis dan secara langsung antara penulis dan pihak Badan Wakaf Indonesia. Selain itu, data sekunder dapat diperoleh dari studi pustaka, yaitu peneliti dapat memperbanyak referensi melalui membaca literatur-literatur yang bersangkutan dengan obyek penelitian (Sugiyono, 2009: 137).

Data merupakan faktor terpenting dalam melaksanakan sebuah penelitian. Dengan demikian, teknik dalam pengumpulan data diperlukan guna untuk memperoleh data yang akurat, relevan dan tepat pada sasaran, sehingga penelitian akan dapat dilaksanakan sebagaimana yang telah direncanakan dan memperoleh hasil yang baik. Adapun teknik pengumpulan data dalam hal ini dapat dilakukan dengan teknik wawancara dan kuesioner (Sugiyono, 2013 : 504).

Teknik analisis data yang akan digunakan dalam melakukan penelitian 
akan dilaksanakan dalam beberapa tahap yaitu:

\section{Statistik Deskriptif}

Statistik deskriptif adalah metode yang digunakan untuk menganalisis data kuesioner yang telah diisi oleh para responden atau nazhir dengan mencari nilai rata-rata pada tabel, sehingga akan diperoleh hasil persentase dari masingmasing pertanyaan. Adapun rumus yang dapat digunakan dalam perhitungan ini adalah:

$\mathrm{P}=(\mathrm{f} / \mathrm{n}) \mathrm{X} 100 \%$

Keterangan:

$\mathrm{P} \quad=$ Persentase

$\mathrm{F} \quad=$ Frekwensi dari jawaban yang

dipilih responden

$\mathrm{N}=$ Jumlah responden.

Adapun standar kriteria nilai yang

ditentukan adalah:

Sangat Setuju $\quad=4$

Setuju $\quad=3$

Tidak Setuju $\quad=2$

Sangat Tidak Setuju $=1$

2. Uji Validitas

Uji validitas adalah tindakan yang dilakukan untuk menguji secara bertahap hasil pengisian kuesioner yang telah diisi oleh para responden. Hal tersebut dilakukan dengan tujuan untuk mengukur ketepatan dan kecermatan hasil dari jawaban yang telah diberikan responden melalui kuesioner, sehingga data yang diperoleh peneliti akan sesuai dengan diadakannya penelitian tersebut. Adapun rumus yang digunakan untuk mengetahui alat ukur validitas adalah dengan korelasi product moment, yaitu (Umar, 2003: 120 dan Sugiyono, 2013: 172):

$$
=\frac{\frac{\sum x y-\left\{\sum x\right\}\left\{\sum y\right\}}{N}}{\sqrt{\left\{\frac{\sum x^{2}-\left(\sum x\right)^{2}}{N}\right\}\left\{\frac{\sum y^{2}-\left(\sum y\right)^{2}}{N}\right\}}}
$$

Keterangan:

rxy : Koefisien korelasi antara $\mathrm{x}$ dan $\mathrm{y} \mathrm{r}_{\mathrm{xy}}$

$\mathrm{N} \quad$ : Jumlah subyek

$\mathrm{X} \quad$ : Skor item

$\mathrm{Y} \quad$ : Skor total

$\sum \mathrm{X} \quad$ : Jumlah skor items

$\sum \mathrm{Y} \quad$ : Jumlah skor total

$\sum \mathrm{X}^{2} \quad$ : Jumlah kuadrat skor item

$\sum \mathrm{Y}^{2} \quad$ : Jumlah kuadrat skor total

3. Uji Reliabilitas

Uji reliabilitas adalah proses pengukuran yang dilakukan terhadap suatu ketepatan dari variabel yang telah ditentukan, yaitu profesionalisme nazhir (X1), program terlaksana secara optimal (X2), dan keuntungan investasi wakaf tunai (X3). Uji reliabilitas dilakukan dengan cara berulang-ulang, jika hasil menunjukkan angka yang sama maka hal tersebut dapat mencapai tujuan dilakukannya uji reliabilitas, yaitu untuk menjamin bahwa ketiga variabel telah reliabel. Untuk mengetahui ketepatan uji reliabititas tersebut, dapat digunakan rumus alpha sebagai berikut (Supranto, 2002: 60, dan Sugiyono, 2013: 178):

$$
r_{11}=\frac{k}{k-1} \times\left\{1-\frac{\sum S_{i}}{S_{t}}\right\}
$$

Dimana :

$\mathrm{r}_{11}=$ Nilai reliabilitas

$\sum \mathrm{S}_{\mathrm{i}} \quad=$ Jumlah varians skor tiap tiap item

$\mathrm{S}_{\mathrm{t}} \quad=$ Varians total

$\mathrm{k}=$ Jumlah item

Jika hasil kuesioner menunjukkan nilai alpha lebih dari 50\% atau 0,5, maka kuesioner dianggap reliabel. Sebaliknya jika hasil kurang dari 50\% atau 0,5 maka kuesioner tersebut tidak reliabel. (Ferdinand, 2006: 196).

\section{Importance Performance Analysis (IPA)}

Metode Importance Performance Analysis (IPA) pertama kali dikenalkan oleh Martilla dan James pada tahun 1977, yaitu 
suatu metode yang digunakan untuk menganalisa suatu penelitian dengan cara membandingkan antara harapan dan kenyataan. Metode ini dapat mengolah data secara matriks dengan cara mengambil nilai rata-rata yang diperoleh dari penilaian responden mengenai keefektifan pengelolaan wakaf tunai di Badan Wakaf Indonesia. Adapun rumus yang dapat diterapkan dalam menganalisis obyek penelitian melalui metode Importance Performance Analysis (IPA) menurut Martilla dan James (Supranto, 2006) adalah:

$$
\mathrm{Tki}=\frac{\mathrm{Xi}}{\mathrm{Yi}} \times 100 \%
$$

Keterangan:

Tki : Tingkat kesesuaian responden

Xi : Skor penilaian kinerja perusahaan

Yi : Skor penilaian kepentingan pelanggan

Selain itu, dibutuhkan nilai rata-rata dari harapan dan kenyataan untuk dapat dianalisis dan dijadikan sebagai batas kuadran dalam diagram IPA. Dengan demikian, untuk memperoleh nilai ratarata dari tersebut dapat menggunakan rumus sebagai berikut:

$$
\mathrm{X}=\frac{\sum \mathrm{Xi}}{\mathrm{n}} \operatorname{dan} \mathrm{Y}=\frac{\sum \mathrm{Yi}}{\mathrm{n}}
$$

Keterangan:

$\mathrm{Xi}=$ Indeks kenyataan atau rata-rata tingkat kenyataan indikator.

$\mathrm{Yi}=$ Indeks kepentingan atau rata-rata tingkat kepentingan indikator

$\mathrm{N}=$ Jumlah responden

Dengan demikian, perolehan nilai ratarata tersebut akan diakumulasikan ke dalam diagram katesius yang terdiri dalam empat kuadran yaitu:

a. Kuadran A, pada kuadran ini terdapat faktor-faktor yang dianggap penting dan sangat berpengaruh terhadap keefektifan pengelolaan wakaf di Badan Wakaf Indonesia, namun pihak Badan Wakaf Indonesia belum dapat merealisasikan keefektifan tersebut sebagaimana yang diharapkan. Dengan demikian, Badan Wakaf Indonesia memiliki tanggung jawab yang tinggi untuk dapat mengoptimalkan indikatorindikator yang terdapat pada kuadran ini.

b. Kuadran B, pada kuadran ini terdapat indikator-indikator penting kedua setelah indikator yang terdapat pada kuadran A. Namun, Badan Wakaf Indonesia harus dapat mempertahankan terlaksananya indikator-indikator tersebut, sehingga dapat menunjang terlaksananya indikator yang terletak pada kuadran A.

c. Kuadran C, pada kuadran ini menunjukkan adanya beberapa indikator yang dianggap tidak memberikan pengaruh secara signifikan terhadap kefektifan pengelolaan wakaf tunai di Badan Wakaf Indonesia. Sehingga pihak nazhir Badan Wakaf Indonesia tidak perlu meningkatkan pelaksanaan program-program tersebut.

d. Kuadran D, pada kuadran ini terdapat indikator-indikator yang dianggap sangat tidak berpengaruh terhadap keefektifan pengelolaan wakaf tunai di Badan Wakaf Indonesia, sehingga pihak nazhir Badan Wakaf Indonesia dapat mengalihkan kegiatan pelaksanaan program-program tersebut pada indikator lain yang dianggap lebih penting dan dapat menunjang keefektifan pengelolaan wakaf tunai. (Fanani, 2011: 191 dan Supranto, 2006).

5. Analisis Efektivitas Pengelolaan Wakaf Tunai di Badan Wakaf Indonesia. 
Metode yang digunakan dalam menganalisis tingkat efektivitas pengelolaan wakaf tunai di Badan Wakaf Indonesia adalah Customer Satisfaction Index (CSI). Customer Satisfaction Index digunakan untuk mengetahui tingkat keefektifan dari terlaksananya programprogram yang telah direncanakan Badan Wakaf Indonesia dalam mengelola wakaf tunai. Adapun dalam mengukur tingkat keefektifan tersebut dapat dilakukan beberapa pertimbangan melalui tahapantahapan yaitu (Syukri, 2014: 107, Andy, 2006: 93):

a. Menentukan tingkat Mean Importance Score (MIS) terhadap setiap variabel.

b. Membuat Weight Factors (WF) pada setiap variabel. Bobot ini merupakan nilai dari seluruh total MIS.

c. Menentukan Mean Statisfaction Score (MSS) pada setiap indikator yang diperoleh dari rata-rata tingkat kinerja dibagi dengan jumlah responden.

d. Menentukan Weight Score (WS) dengan cara mengalikan nilai WS dengan MSS.

e. Menentukan nilai Customer Satisfaction Index (CSI).

Adapun penilaian Customer Satisfaction Index (CSI) dapat ditentukan melalui kriteria penilaian CSI sebagai berikut:
Tabel 1. Kriteria Nilai CSI

\begin{tabular}{|l|l|l|}
\hline NO & Indeks CSI & Parameter \\
\hline 1 & $90,01-100 \%$ & Excellent \\
\hline 2 & $70,01-90,00 \%$ & Satisfied \\
\hline 3 & $50,01-70,00 \%$ & Average \\
\hline 4 & $25,01-50,00 \%$ & Unsatisfied \\
\hline 5 & $0-25,00 \%$ & $\begin{array}{c}\text { Very } \\
\text { Unsatisfied }\end{array}$ \\
\hline
\end{tabular}

Sumber : Silaningsih, Endang. Gemina, Dwi. 2015

\section{HASIL DAN PEMBAHASAN}

\section{A. Profil Badan Wakaf Indonesia}

Badan Wakaf Indonesia dibentuk berdasarkan Undang-Undang Nomor 41 Tahun 2004 yang menjelaskan tentang wakaf. Setelah itu, terbit Peraturan Pemerintah Nomor 42 Tahun 2006 Tentang Keputusan Pelaksanaan UndangUndang Nomor 41 Tahun 2004 pada tanggal 15 Desember Tahun 2006. Barulah kemudian pada tanggal 13 Juli 2007 terbitlah Keputusan Presiden Nomor 75/M yang menyatakan tentang didirikannya Badan Wakaf Indonesia. Keputusan Presiden tersebut juga berlaku pada penentuan anggota Badan Wakaf Indonesia yang dapat diajukan oleh menteri agama. Namun, pada periode selanjutnya, pengajuan calon anggota Badan Wakaf Indonesia dilakukan oleh panitia yang telah dibentuk oleh Badan Wakaf Indonesia.

Berdasarkan Keputusan Presiden tersebut, maka terpilihlah KH. Tholhah Hasan sebagai ketua Badan Wakaf Indonesia periode pertama terhitung sejak tanggal 13 Juli 2007. Pada periode kedua, tanggal 9 Juni 2011 melalui Keputusan Presiden Nomor 111/M Tahun 2011 terpilih kembali KH. Thalhah Hasan sebagai ketua Badan Wakaf Indonesia. Sedangkan pada periode ketiga, melalui Peraturan Presiden Nomor 117/M Tahun 2014 terpilih Maftuh Basyuni sebagai ketua 
Badan Wakaf Indonesia. Adapun masa jabatan anggota Badan Wakaf Indonesia setiap periodenya adalah tiga tahun. Namun setiap anggota dapat diangkat selama dua periode melalui pemilihan yang dilakukan oleh presiden.

Pusat Badan Wakaf Indonesia didirikan di Ibu Kota Jakarta, namun Badan Wakaf Indonesia dapat membentuk perwakilanperwakilan Badan Wakaf Indonesia disetiap daerah sebagaimana yang dibutuhkan, dan memiliki wewenang untuk mengangkat atau memberhentikan keanggotaan perwakilan Badan Wakaf Indonesia.

Sebagai badan hukum yang independen dan didukung penuh orientasinya oleh Undang-Undang dan pemerintah, Badan Wakaf Indonesia memiliki visi dan misi tertentu dalam melaksanakan tugasnya, yaitu:

\section{Visi}

Terwujudnya lembaga independen yang dipercaya masyarakat, mempunyai kemampuan dan integritas untuk mengembangkan perwakafan nasional dan internasional.

\section{Misi}

Menjadikan Badan Wakaf Indonesia sebagai lembaga profesional yang mampu mewujudkan potensi dan manfaat ekonomi harta benda wakaf untuk kepentingan ibadah dan pemberdayaan masyarakat.

Badan Wakaf Indonesia memiliki tugas dan wewenang dalam melaksanakan kegiatannya yang berkaitan dengan harta benda wakaf. Adapun tugas dan wewenang Badan Wakaf Indonesia dibentuk lebih rinci yang tercantum dalam Peraturan Badan Wakaf Indonesia Nomor 1 Tahun 2007 tentang Organisasi dan Tata Kerja Badan Wakaf Indonesia, yaitu: a. Melakukan pembinaan terhadap nazhir dalam mengelola dan mengembangkan harta benda wakaf.

b. Membuat pedoman pengelolaan dan pengembangan harta benda wakaf.

c. Melakukan pengelolaan dan pengembangan harta benda wakaf berskala nasional dan internasional serta harta benda wakaf yang terlantar.

d. Memberikan pertimbangan, persetujuan, dan/atau izin atas perubahan peruntukan dan status harta benda wakaf.

e. Memberikan pertimbangan dan/atau persetujuan atas penukaran harta benda wakaf.

f. Memberikan saran dan pertimbangan kepada Pemerintah dalam penyusunan di bidang perwakafan.

g. Menerima, melakukan penilaian, menerbitkan tanda bukti pendaftaran nazhir, dan mengangkat kembali nazhir yang telah habis masa baktinya.

h. Badan Wakaf Indonesia dapat bertindak memberhentikan atau mengganti nazhir jika hal tersebut lebih baik.

i. Memberikan saran dan pertimbangan kepada Menteri Agama dalam menunjuk Lembaga Keuangan Syariah Penerima Wakaf Uang (LKS-PWU).

j. Menerima pendaftaran Akta Ikrar Wakaf (AIW) benda bergerak selain uang dari Pejabat Pembuat Akta Ikrar Wakaf (PPAIW).

\section{Analisis Deskriptif Kuantitatif}

Berdasarkan pada teknik pengumpulan data yang telah ditentukan oleh peneliti, untuk memperoleh data dalam menganalisis penelitian ini, telah diajukan kuesioner kepada beberapa nazhir yang telah dipilih sebagai responden. Kuesioner tersebut diberikan kepada para nazhir yang terdapat di Badan Wakaf Indonesia atau para pengelola wakaf lainnya yang 
memiliki profesi sebagai nazhir. Seperti nazhir yang bertugas di berbagai lembaga keuangan syariah, dan para pengelola yayasan tanah wakaf.

Pengajuan kuesioner ini dilakukan dengan tujuan untuk memperoleh data secara jelas dari para responden dari berbagai aspek. Seperti jenis kelamin responden, usia, pendidikan terakhir dan latar belakang pendidikan responden. Selain itu, terdapat beberapa variabel yang wajib diisi oleh para responden meliputi seluruh cakupan kegiatan nazhir sebagai pengelola wakaf, baik penghimpunan, pengelolaan, keuntungan investasi, sampai kepada penyaluran hasil yang diperoleh dari pengelolaan wakaf tersebut. Dengan demikian, peneliti akan mendapatkan hasil penelitian yang diperoleh dari jawaban responden melalui kuesioner, sehingga peneliti dapat membuat kesimpulan yang akurat. Adapun jumlah kuesioner yang telah diberikan kepada responden berjumlah 30 kuesioner.

\section{Analisis Data Demografi Responden Demografi Jenis Kelamin}

Setelah seluruh kuesioner diisi oleh para responden, maka dapat diketahui jumlah dari masing-masing jenis kelamin responden, baik laki-laki maupun perempuan. Dari 30 kuesioner yang telah terisi, 16 kuesioner diisi oleh responden dengan jenis kelamin laki-laki, sedangkan 14 kuesioner diisi oleh responden perempuan.

Jumlah responden atau nazhir didominasi oleh laki-laki, yaitu dengan persentase $55 \%$ atau sebanyak 16 orang responden. Pada dasarnya, jenis kelamin laki-laki atau perempuan tidak menjadi syarat utama untuk menjadi nazhir. Namun, sesuai dengan keadaan nazhir di Badan Wakaf Indonesia, yaitu lebih di dominasi oleh nazhir laki-laki daripada perempuan. Badan Wakaf Indonesia lebih mengutamakan nazhir laki-laki karena lebih fleksibel untuk dapat bekerja, baik di lingkungan area kantor maupun melakukan pengembangan harta wakaf di luar area kantor. Sedangkan nazhir perempuan lebih dominan hanya untuk menyelesaikan pekerjaan yang berada di lingkungan kantor.

\section{Demografi Usia Responden}

Batasan-batasan kriteria usia responden dibagi menjadi empat kriteria, yaitu 18-23 tahun, 24-29 tahun, 30-40 tahun, dan $>40$ tahun. Usia dari 30 responden tampak sangat variatif, yaitu 12 responden berusia 18-23 tahun, 9 responden berusia 24-29 tahun, 4 responden berusia 30-40 tahun, dan 5 responden berusia $>40$ tahun. Dengan demikian, menunjukkan bahwa usia nazhir di dominasi oleh batasan usia 18-23 tahun. Batas usia 18-23 tersebut akan mempengaruhi tingkat keahlian yang dimiliki oleh nazhir dalam mengelola wakaf. Selain pengetahuan, dalam mengelola wakaf juga dibutuhkan faktor lain seperti pengalaman, kemampuan dalam menyelesaikan sengketa wakaf, dan keahlian lainnya. Faktor pengalaman secara mayoritas dimiliki oleh orang-orang dengan batas usia diatas 18-23 tahun. Sedangkan usia 18-23 tahun sebagaimana perolehan demografi usia nazhir di Badan Wakaf Indonesia, masih tergolong angkatan kerja baru.

\section{Demografi Jabatan Responden}

Secara khusus, responden yang dibutuhkan dalam penelitian ini adalah seorang pengelola wakaf atau nazhir. Namun pada umumnya adalah seseorang yang ahli dalam bidang keilmuan wakaf, baik wakaf tanah, bangunan, maupun wakaf uang. Dengan demikian, tidak menutup kemungkinan dari 30 responden 
yang diambil oleh peneliti memiliki profesi yang berbeda dalam mengelola wakaf, bahkan memungkinkan terjadi adanya rangkap jabatan yang dimiliki oleh seseorang yang sedang menjabat sebagai nazhir.

Responden memiliki profesi yang sangat berbeda-beda, yaitu 21 responden sebagai guru, 1 responden sebagai kepala sekolah, 3 responden sebagai pimpinan pesantren, 2 responden sebagai staf keuangan Pos Peduli Keadilan Ummat, 2 responden sebagai staf Badan Wakaf Indonesia, dan 1 responden sebagai Customer Relation Management Pos Peduli Keadilan Ummat. Dengan demikian, dari keseluruhan jabatan yang dimiliki responden tersebut secara mayoritas di dominasi oleh guru, yaitu dengan persentase $50 \%$ menjabat sebagai guru, atau sebanyak 15 responden.

Profesi guru merupakan pekerjaan yang dianggap tidak mengikat dan tidak menghabiskan waktu secara intensif, sehingga $50 \%$ dari nazhir memilih profesi guru sebagai pekerjaan lain selain mengelola wakaf.

\section{Demografi Pendidikan Terakhir Responden.}

Berkaitan dengan jabatan yang dimiliki oleh responden, pendidikan terakhir merupakan salah satu faktor yang menjadi penentu posisi dalam sebuah jabatan. Selain itu, faktor pendidikan merupakan penentu keilmuan yang dimiliki seseorang untuk dapat diterapkan dalam dunia kerja, sehingga sumber daya manusia tersebut dapat bekerja secara efisien.

Tingkat pendidikan terakhir para responden berada pada tiga tingkatan yaitu SMA/sederajat, S1, dan S2, dengan masingmasig persentase pendidikan terakhir SMA/sederajat sebanyak 13 responden, S1 sebanyak 15 responden, dan S2 sebanyak 2 responden. Sehingga kesimpulan yang dapat diambil adalah pendidikan terakhir dengan strata 1 atau S1 yaitu sebanyak 15 orang atau $50 \%$ dari 30 responden. Hasil dari kesimpulan pendidikan terakhir responden tersebut telah sesuai dengan sumber daya yang dibutuhkan dalam mengelola wakaf, karena pendidikan terakhir responden akan dihubungkan dengan keahlian yang dimiliki oleh responden.

\section{Demografi Latar Belakang Pendidikan Responden.}

Latar belakang pendidikan dari 30 responden secara mayoritas di dominasi oleh Ilmu Pengetahuan Agama, yaitu dengan persentase $36 \%$ atau sebanyak 11 responden. Adapun responden lainnya berasal dari latar pendidikan yang berbeda-beda yaitu 10 responden memiliki latar belakang pendidikan Ilmu Pengetahuan Sosial atau dengan persentase 33\%, 3 responden memiliki latar belakang pendidikan dari Ilmu Pengetahuan Alam atau dengan persentase $10 \%$, dan 6 responden terakhir memiliki latar belakang pendidikan selain dari Ilmu Pengetahuan Alam, Ilmu Pengetahuan Sosial, dan Ilmu Pengetahuan Agama dengan persentase $20 \%$.

Latar belakang pendidikan responden akan mempengaruhi tingkat pengetahuan nazhir, sehingga nazhir dapat mengelola wakaf sesuai dengan yang dibutuhkan. Selain dari Ilmu Pengetahuan Agama sebagaimana perolehan tertinggi dari demografi latar belakang pendidikan nazhir, nazhir juga membutuhkan keilmuan lain seperti Ilmu Pengetahuan Sosial (manajemen, akuntansi, dan lain-lain), sehingga nazhir memiliki pengetahuan yang sesuai dengan yang dibutuhkan dan dapat mengelola wakaf sesuai dengan prosedur. 
Penilaian selanjutnya adalah melalui tingkat kepentingan dan kenyataan berdasarkan pada masing-masing variabel. Adapun variabel yang telah ditentukan dalam penelitian ini meliputi profesionalisme nazhir $\left(\mathrm{X}_{1}\right)$, program terlaksana secara optimal $\left(\mathrm{X}_{2}\right)$, dan adanya keuntungan dari investasi dana wakaf tunai yang diraih $\left(\mathrm{X}_{3}\right)$.

\section{Profesionalisme Nazhir ( $\left.\mathrm{X}_{1}\right)$ Sifat Rosulullah SAW.}

Harapan responden mengenai empat kriteria yang harus dipenuhi oleh nazhir seperti shiddiq, amanah, tabligh, dan fathanah untuk dapat mengelola wakaf secara efektif, yaitu 9 responden menyatakan sangat setuju dengan persentase 30\%, dan 21 responden menyatakan setuju dengan persentase 70\%. Sehingga, tidak terdapat responden yang menyatakan tidak setuju dan sangat tidak setuju.

Pentingnya shiddiq, amanah, tabligh, dan fathanah yang harus dipenuhi oleh nazhir tersebut karena dana yang dikelola nazhir (wakaf) merupakan dana titipan umat yang harus digunakan untuk kesejahteraan umat kembali. Sehingga tidak akan dipilih menjadi nazhir apabila tidak memiliki sifat jujur, pandai, dan sifatsifat terpuji lainnya.

Responden yang telah memenuhi empat kriteria nazhir yang dibutuhkan yaitu shiddiq, amanah, tabligh, dan fathanah. Sehingga nazhir yang telah mengelola wakaf saat ini dapat dikategorikan telah memenuhi syarat utama untuk menjadi seorang nazhir yang mengelola wakaf sebagaimana yang dibutuhkan. Hal tersebut berdasarkan pada persentase $40 \%$ atau sebanyak 12 responden yang menyatakan sangat memenuhi empat utama kriteria nazhir. Adapun 18 responden lainnya dinyatakan telah memenuhi kriteria dengan persentase $60 \%$.

\section{Kreativitas Nazhir}

Responden terhadap tingginya tingkat kreativitas yang harus dimiliki oleh nazhir, yaitu sebanyak 12 responden diantaranya menyatakan sangat setuju dengan persentase $30 \%$, adapun 18 responden lainnya menyatakan setuju. Dengan demikian, tidak terdapat responden yang menyebutkan tidak setuju dan sangat tidak setuju terhadap pernyataan tersebut. Harapan tersebut sesuai dengan kebutuhan nazhir dalam mengelola wakaf, yaitu tidak hanya membutuhkan kejujuran dan kecerdasa, namun seorang nazhir juga harus mampu dalam mengembangkan harta wakaf melalui program-program yang kreatif dan inovatif. Sehingga harta wakaf akan tumbuh secara baik untuk mensejahterakan umat.

Kenyataan responden mengenai adanya kreativitas tinggi yang harus dimiliki oleh setiap nazhir, yaitu terdapat 14 responden dinyatakan memiliki kreativitas tinggi dengan persentase 46.66 $\%$, adapun 16 responden lainnya dengan persentase $53.33 \%$ dinyatakan tidak memiliki kreativitas yang tinggi dalam mengelola harta wakaf. Rendahnya tingkat kreativitas yang dimiliki oleh nazhir akan menyebabkan rendahnya tingkat produktivitas harta wakaf yang dikelola oleh nazhir. Dengan demikian, harta wakaf akan dikelola dengan metode yang sama atau tidak terdapat pembaharuan terhadap pogram yang dianggap tidak produktif, sehingga manfaat dari harta wakaf akan sulit diperoleh masyarakat.

\section{Pelatihan-Pelatihan Pengelolaan Wakaf Oleh Nazhir}

Dari hasil penelitian didapati 22 responden menyatakan sangat setuju terhadap adanya pelatihan-pelatihan 
pengelolaan wakaf yang diberikan kepada nazhir dengan persentase sebesar $73.33 \%$. Adapun 8 responden lainnya memberikan pernyataan setuju dengan persentase 26.67\%. Dengan demikian, tidak terdapat responden yang menyebutkan tidak setuju dan sangat tidak setuju terhadap pernyataan tersebut.

Kenyataan responden terhadap pelatihan-pelatihan pengelolaan wakaf yang diberikan kepada nazhir, yaitu sebanyak 23 responden menyatakan bahwa pelatihan-pelatihan nazhir telah terlaksana dengan persentase $46.67 \%$. Adapun 7 responden lainnya menyatakan tidak terdapat pelaksanaan pelatihanpelatihan terhadap nazhir mengenai tata cara pengelolaan wakaf yang efektif dengan persentase $23.33 \%$. Pentingnya pelatihan pengelolaan wakaf adalah untuk menambah wawasan dan kreativitas bagi nazhir, sehingga nazhir dapat memahami secara detail tentang tugas-tugas yang harus dilakukan. Namun berdasarkan data yang telah diperoleh, pelatihan-pelatihan pengelolaan wakaf dianggap kurang optimal, sehingga nazhir tidak memiliki tingkat kreativitas yang tinggi dalam mengembangkan harta wakaf.

\section{Profesi Lain Yang Dimiliki Nazhir}

Tingkat perbedaan harapan responden mengenai profesi lain yang dimiliki oleh nazhir, yaitu 8 responden menyatakan sangat setuju dengan 26.67\%, 17 responden menyatakan setuju dengan persentase $56.67 \%$ dan 5 responden lainnya menyebutkan harapannya dengan tidak setuju terhadap profesi lain yang dimiliki oleh nazhir. Berbedanya persepsi nazhir mengenai rangkap jabatan nazhir akan menimbulkan permasalahan baru, yaitu profesi nazhir dianggap sebagai pekerjaan sampingan dan tidak memberikan insentif sesuai dengan kebutuhan nazhir, sehingga tidak sedikit jumlah nazhir yang menyetujui adanya profesi lain yang dimiliki oleh nazhir.

Kenyataan responden terhadap profesi lain yang dimiliki oleh nazhir. Idealnya, bagi seorang nazhir tidak diperkenankan memiliki profesi lain selain nazhir, karena nazhir tidak akan dapat bekerja secara efisien. Namun berdasarkan dengan data yang diperoleh yaitu 19 responden dinyatakan sangat setuju dan memiliki profesi lain atau rangkap jabatan selain dari nazhir dengan persentase $63.33 \%, 5$ responden dinyatakan memiliki profesi lain dengan persentase 16.67\%, dan 6 responden lainnya menyatakan tidak memiliki profesi selain dari nazhir. Dengan demikian, secara mayoritas nazhir pengelola wakaf yang ada pada saat ini memiliki profesi lain selain nazhir. Sehingga menyebabkan nazhir tidak dapat bekerja secara proporsional, karena nazhir tidak terfokus pada satu pekerjaan.

Pelaksanaan Program Secara Optimal $\left(\mathrm{X}_{2}\right)$

\section{Strategi-strategi fundraising oleh Badan Wakaf Indonesia.}

Harapan responden terhadap adanya strategi-strategi yang diimplementasikan oleh Badan Wakaf Indonesia dalam melakukan fundraising, yaitu 11 responden memberikan pernyataan sangat setuju dengan persentase $36.67 \%$, dan 19 responden lainnya menyatakan setuju dengan persentase 63.33\%. Dengan demikian, tidak terdapat responden yang menyatakan tidak setuju dan sangat tidak setuju terhadap strategi-strategi fundraising yang diimplementasikan oleh Badan Wakaf Indonesia.

Kenyataan responden terhadap strategi-strategi fundraising yang diimplementasikan oleh Badan Wakaf Indonesia, yaitu 4 responden memberikan 
kenyataan sangat terlaksana dengan persentase $13.33 \%$, dan 26 responden lainnya memberikan kenyataan terlaksana dengan persentase $86.67 \%$ terhadap adanya pelaksanaan strategi fundraising tersebut. Adapun startegi fundraising yang diimplementasikan oleh Badan Wakaf Indonesia adalah dengan melakukan kerja sama dengan pihak-pihak tertentu untuk menghimpun dana wakaf. Seperti bekerja sama dengan Badan Amil Zakat Nasional, penyeluran melalui rekening nasabah Bank Syariah Mandiri, BNI Syariah, dan bankbank lainnya yang telah ditunjuk sebagai Lembaga Penerima Wakaf Uang (LKSPWU).

\section{Target Dalam Melakukan Fundraising.}

Harapan responden mengenai adanya target dalam melakukan fundraising, yaitu sebanyak 11 responden memberikan pernyataan sangat setuju dengan persentase 36.67\%. Adapun 19 responden lainnya menyatakan setuju dengan persentase 63.33\%. Dengan demikian, tidak terdapat responden yang menyatakan tidak setuju dan sangat tidak setuju terhadap adanya target dalam melakukan fundraising. Target fundraising tidak hanya dibutuhkan untuk menambah jumlah besaran wakaf, namun juga dapat diterapkan untuk menambah pengetahuan masyarakat mengenai keberadaan wakaf tunai. Sehingga akan memotivasi masyarakat untuk melakukan wakaf tunai. Dengan demikian, seiring dengan luasnya pengetahuan masyarakat tentang wakaf tunai, maka akan meningkat pula pertumbuhan perolehan wakaf tunai yang dapat dikembangkan dalam berbagai program yang telah direncanakan.

Kenyataan responden terhadap target dalam melakukan fundraising, yaitu 3 responden memberikan kenyataan terlaksana dengan persentase $10 \%, 26$ responden memberikan kenyataan tidak terlaksana dengan persentase $86.67 \%$, dan 1 responden menyatakan sangat tidak terlaksana terhadap adanya target dalam melakukan fundraising. Banyaknya responden yang menyatakan bahwa tidak terdapat target dalam melakukan fundraising didasarkan pada persepsi para nazhir yang beranggapan bahwa wakaf merupakan bagian shadaqah yang tidak berhukum wajib seperti zakat. Sehingga dalam melakukan fundraising nazhir hanya melaksanakan secara sukarela. Persepsi ini sangat berbeda dengan tindakan yang seharusnya dilakukan oleh nazhir, bahwa fundraising semata-mata tidak hanya dilakukan untuk menambah jumlah besaran wakaf, namun juga untuk menambah pengetahuan masyarakat dalam mengenal keberadaan wakaf tunai.

\section{Pelayanan Donasi Wakaf Melalui Berbagai Fitur}

Harapan responden mengenai pelayanan donasi wakaf melalui berbagai fitur (auto debet, bayar secara langsung, transfer via ATM, Internet banking), yaitu sebanyak 14 responden memberikan pernyataan sangat setuju dengan persentase 46.67\%. Adapun 16 responden lainnya menyatakan setuju dengan persentase 53.33\%. Dengan demikian, tidak terdapat responden yang menyatakan tidak setuju dan sangat tidak setuju terhadap adanya pelayanan donasi wakaf tersebut.

Kenyataan responden terhadap pelayanan donasi wakaf melalui berbagai fitur (auto debet, bayar secara langsung, transfer via ATM, internet banking), yaitu 17 responden memberikan kenyataan sangat terlaksana dengan persentase $56.67 \%$, dan 13 responden lainnya memberikan kenyataan terlaksana dengan persentase $43.33 \%$. Dengan demikian, 
tidak terdapat responden yang menyatakan tidak terlaksana dan sangat tidak terlaksana terhadap adanya pelayanan donasi wakaf melalui fitur-fitur tersebut. Berdasarkan pada hasil kuesioner yang diperoleh, program ini dinyatakan telah terlaksana secara maksimal. Penyaluran dana wakaf melalui media elektronik ini telah dilaksanakan oleh beberapa bank yang menerima wakaf uang dengan cara tertentu, seperti menyediakan fasilitas rekening, fasilitas online, dan memberikan penawaran kepada setiap nasabah yang melakukan transaksi via ATM untuk dapat mewakafkan uangnya sebesar Rp. 1000.

\section{Administrasi Dana Wakaf}

Harapan responden terhadap diterapkannya administrasi dana wakaf, yaitu 15 responden memberikan kenyataan sangat setuju dengan persentase 50\%, dan 15 responden lainnya memberikan kenyataan setuju dengan persentase 50\%. Dengan demikian, tidak terdapat responden yang menyatakan tidak setuju dan sangat tidak setuju terhadap diterapkannya administrasi dana wakaf tersebut. Kegiatan administrasi dana wakaf merupakan tugas pertama yang harus dilakukan oleh nazhir setelah terdapat penyetoran dana wakaf, sehingga pencatatan keuangan dana wakaf dapat diketahui secara jelas baik oleh wakif maupun untuk kepentingan publik. Dengan demikian, peran ini juga merupakan salah satu fungsi dibutuhkannya seorang nazhir yang tidak hanya mahir dalam bidang keagamaan dan yang lainnya, tapi juga dalam bidang akuntansi.

Kenyataan responden mengenai diterapkannya administrasi dana wakaf, yaitu sebanyak 12 responden memberikan pernyataan bahwa administrasi pada dana wakaf tunai sangat diterapkan dengan persentase 40\%. Adapun 18 responden lainnya menyatakan bahwa administrasi atau pencatatan dana wakaf diterapkan dengan persentase 60\%. Dengan demikian, secara keseluruhan dapat disimpulkan bahwa administrasi wakaf telah dilaksanakan. Secara rata-rata seluruh nazhir telah melaksanakan pencatatan terhadap penerimaan dana wakaf, sehingga hal tersebut dapat memudahkan nazhir dalam membuat laporan yang akan diberikan kepada nazhir maupun pihak lain yang terkait. Namun belum diketahui mengenai ketransparanan pencatatan dana wakaf tersebut.

\section{Investasi Dana Wakaf Tunai}

Harapan responden mengenai dilaksanaknnya investasi dana wakaf tunai pada sektor-sektor keuangan sesuai dengan instrumen syariah, yaitu sebanyak 11 responden memberikan pernyataan sangat setuju dengan persentase $36.67 \%$. Adapun 19 responden lainnya menyatakan setuju dengan persentase 63.33\%. Dengan demikian, tidak terdapat responden yang menyatakan tidak setuju dan sangat tidak setuju terhadap diterapkannya investasi dana wakaf tunai pada sektor-sektor keuangan tersebut.

Kenyataan responden terhadap dilaksanakannya investasi dana wakaf tunai pada sektor-sektor keuangan sesuai dengan instrumen syariah, yaitu 3 responden memberikan kenyataan bahwa program tersebut sangat terlaksana dengan persentase $10 \%$, dan 27 responden lainnya memberikan kenyataan tidak terlaksana dengan persentase 90\%. Dengan demikian, investasi dana wakaf tunai pada sektorsektor keuangan belum dilaksanakan sebagaimana yang telah diharapkan.

Investasi Dana Wakaf Tunai Pada Sektor-Sektor Riil.

Harapan responden mengenai dilaksanakannya investasi dana wakaf 
tunai pada sektor-sektor riil, yaitu sebanyak 18 responden memberikan pernyataan sangat setuju dengan persentase 60\%. Adapun 12 responden lainnya menyatakan setuju dengan persentase $40 \%$. Dengan demikian, tidak terdapat responden yang menyatakan tidak setuju dan sangat tidak setuju terhadap diterapkannya investasi dana wakaf tunai pada sektor-sektor riil tersebut.

Kenyataan responden terhadap dilaksanakannya investasi dana wakaf tunai pada sektor-sektor riil, yaitu 27 responden memberikan kenyataan tidak terlaksana dengan persentase $90 \%$, dan 3 responden lainnya memberikan kenyataan sangat tidak terlaksana dengan persentase $10 \%$. Dengan demikian, investasi dana wakaf tunai pada sektor-sektor riil belum dilaksanakan sebagaimana yang telah diharapkan.

\section{Penyaluran Dana Wakaf Tunai Pada Sektor-Sektor Sosial.}

Harapan responden mengenai dilaksanakannya penyaluran dana wakaf tunai pada sektor-sektor sosial, yaitu sebanyak 18 responden memberikan pernyataan sangat setuju dengan persentase 60\%. Adapun 12 responden lainnya menyatakan setuju dengan persentase $40 \%$. Dengan demikian, tidak terdapat responden yang menyatakan tidak setuju dan sangat tidak setuju terhadap penyaluran dana wakaf tunai pada sektorsektor sosial tersebut.

Kenyataan responden terhadap penyaluran dana wakaf tunai pada sektorsektor sosial, yaitu 21 responden memberikan kenyataan bahwa program tersebut sangat terlaksana dengan persentase $70 \%$, dan 9 responden lainnya memberikan kenyataan terlaksana dengan persentase 30\%. Dengan demikian, tidak terdapat responden yang menyatakan tidak terlaksana dan sangat tidak terlaksana terhadap penyaluran dana wakaf tunai pada sektor-sektor sosial.

\section{Penggantian Program Kurang Produktif}

Harapan responden mengenai adanya penggantian program yang kurang produktif, yaitu sebanyak 10 responden memberikan pernyataan sangat setuju dengan persentase 33.33\%. Adapun 20 responden lainnya menyatakan setuju dengan persentase 66.67\%. Dengan demikian, tidak terdapat responden yang menyatakan tidak setuju dan sangat tidak setuju terhadap penggantian program yang kurang produktif tersebut.

Kenyataan responden terhadap penggantian program kurang produktif, yaitu 5 responden memberikan kenyataan bahwa program tersebut telah terlaksana dengan persentase $16.67 \%, 13$ responden memberikan kenyataan tidak terlaksana dengan persentase 43.33\%. Dan 12 responden lainnya menyatakan penggantian program kurang produktif sangat tidak terlaksana dengan persentase $40 \%$.

\section{Adanya Keuntungan Investasi Dana} Wakaf Tunai $\left(\mathrm{X}_{3}\right)$

\section{Keuntungan Investasi Dana Wakaf Tunai}

Harapan responden mengenai keuntungan investasi dana wakaf tunai, yaitu sebanyak 18 responden memberikan pernyataan sangat setuju dengan persentase $\quad 60 \%$. 10 responden menyatakan setuju dengan persentase $33.33 \%$, dan 2 responden lainnya menyatakan tidak setuju dengan persentase $66.67 \%$.

Kenyataan responden terhadap adanya keuntungan investasi dana wakaf tunai, yaitu 18 responden memberikan kenyataan bahwa keuntungan investasi dana wakaf tunai sangat terealisasi dengan persentase 
60\%, 10 responden memberikan kenyataan terealisasi dengan persentase 33.33\%. Dan 2 responden lainnya menyatakan sangat tidak terealisasi dengan persentase $6.67 \%$.

Pendistribusian Keuntungan Investasi Kepada Sektor Sosial

Harapan responden mengenai pendistribusian keuntungan investasi kepada sektor sosial (yayasan atau pesantren), yaitu sebanyak 16 responden memberikan pernyataan sangat setuju dengan persentase 53.33\%, dan 14 responden lainnya menyatakan setuju dengan persentase $46.67 \%$. Dengan demikian, pada program pendistribusian keuntungan investasi ini tidak terdapat responden yang menyatakan tidak setuju dan sangat tidak setuju.

Kenyataan responden terhadap adanya pendistribusian keuntungan investasi kepada sektor sosial (yayasan atau pesantren), yaitu 25 responden memberikan kenyataan program tersebut sangat terlaksana dengan persentase 83.33\%, dan 5 responden lainnya memberikan kenyataan terlaksana dengan persentase $16.67 \%$. Dengan demikian, tidak terdapat responden yang memberikan kenyataan tidak terlaksana dan sangat tidak terlaksana pada program pendistribusian tersebut.

Memproduktifkan Kembali Keuntungan Investasi Kepada Sektor Financial

Harapan responden mengenai memproduktifkan kembali keuntungan investasi kepada sektor keuangan, yaitu sebanyak 14 responden memberikan pernyataan sangat setuju dengan persentase $46.67 \%$, dan 16 responden lainnya menyatakan setuju dengan persentase 53.33\%. Dengan demikian, pada program memproduktifkan kembali keuntungan investasi kepada sektor keuangan ini tidak terdapat responden yang menyatakan tidak setuju dan sangat tidak setuju.

Kenyataan responden terhadap adanya program memproduktifkan kembali keuntungan investasi kepada sektor keuangan, yaitu 11 responden memberikan kenyataan tidak terlaksana dengan persentase $36.67 \%$, dan 19 responden lainnya memberikan kenyataan sangat tidak terlaksana dengan persentase 63.33\%. Dengan demikian, pada program ini dapat disimpulkan belum terlaksana sebagaimana seperti yang telah diharapkan oleh nazhir.

\section{Harapan Mengenai Ketransparanan Pengelolaan Wakaf}

Harapan responden mengenai ketransparanan pengelolaan wakaf, yaitu sebanyak 20 responden memberikan pernyataan sangat setuju dengan persentase $66.67 \%$, dan 10 responden lainnya menyatakan setuju dengan persentase 33.33\%. Dengan demikian, tidak terdapat responden yang menyatakan tidak setuju dan sangat tidak setuju terhadap ketransparanan pengelolaan wakaf tersebut.

Kenyataan responden terhadap adanya ketransparanan pengelolaan wakaf, yaitu 10 responden memberikan kenyataan tidak terlaksana dengan persentase $33.33 \%$, dan 20 responden lainnya memberikan kenyataan sangat tidak terlaksana dengan persentase $66.67 \%$. Dengan demikian, pada tahap ini dapat disimpulkan belum terlaksana sebagaimana seperti yang telah diharapkan oleh nazhir.

\section{Ketransparanan Pengelolaan Wakaf Dapat Menambah Jumlah Wakaf Secara Terus-menerus}

Harapan responden mengenai ketransparanan pengelolaan wakaf dapat menimbulkan kepercayaan bagi wakif dan menambah jumlah besaran wakaf secara 
terus-menerus, yaitu sebanyak 18 responden memberikan pernyataan sangat setuju dengan persentase 60\%, dan 12 responden lainnya menyatakan setuju dengan persentase $40 \%$. Dengan demikian, tidak terdapat responden yang menyatakan tidak setuju dan sangat tidak setuju.

Kenyataan responden terhadap ketransparanan pengelolaan wakaf dapat menimbulkan kepercayaan bagi wakif dan menambah jumlah besaran wakaf secara terus-menerus, yaitu 2 responden memberikan kenyataan bahwa harapan tersebut sangat terlaksana dengan persentase 6.67\%, 17 responden memberikan kenyataan terlaksana dengan persentase 56.67\%, dan 11 responden terakhir memberikan kenyataan tidak terlaksana dengan persentase $36.67 \%$.

Ketransparanan Sebagai Motivasi Untuk Berwakaf

Harapan responden mengenai ketransparanan pengelolaan wakaf dapat memotivasi masyarakat untuk berwakaf, yaitu sebanyak 19 responden memberikan pernyataan sangat setuju dengan persentase $63.33 \%$, dan 11 responden lainnya menyatakan setuju dengan persentase $36.67 \%$. Dengan demikian, tidak terdapat responden yang menyatakan tidak setuju dan sangat tidak setuju.

Kenyataan responden terhadap ketransparanan pengelolaan wakaf dapat memotivasi masyarakat untuk berwakaf, yaitu 2 responden memberikan kenyataan sangat terlaksana dengan persentase $6.67 \%, 26$ responden memberikan kenyataan terlaksana dengan persentase 86.67\%, dan 1 responden terakhir memberikan kenyataan tidak terlaksana dengan persentase 3.33\%.

\section{Pertumbuhan Wakaf Di Badan Wakaf Indonesia}

Harapan responden mengenai ketransparanan pengelolaan wakaf dapat menimbulkan pertumbuhan wakaf di Badan Wakaf Indonesia semakin meningkat, yaitu sebanyak 19 responden memberikan pernyataan sangat setuju dengan persentase 63.33\%, dan 11 responden lainnya menyatakan setuju dengan persentase $36.67 \%$. Dengan demikian, tidak terdapat responden yang menyatakan tidak setuju dan sangat tidak setuju.

Kenyataan responden terhadap ketransparanan pengelolaan wakaf dapat memotivasi masyarakat untuk berwakaf, yaitu 9 responden memberikan kenyataan sangat terlaksana dengan persentase $30 \%$, 19 responden memberikan kenyataan terlaksana dengan persentase $63.33 \%$, dan 2 responden terakhir memberikan kenyataan tidak terlaksana dengan persentase $6.67 \%$.

\section{Analisis Data}

Uji reliabilitas digunakan untuk mengukur suatu instrumen penelitian dengan melihat koefisien cronbach's alpha. Dari hasil perhitungan melalui SPSS versi 22. Dari hasil pengujian tersebut, menunjukkan bahwa semua instrumen tersebut dikatakan reliabel karena nilai koefisien cronbach alpha lebih besar dari 0,5 yaitu sebesar 0,981 .

Uji validitas digunakan untuk menguji validitas dari semua instrumen penelitian yang digunakan. Hasil uji validitas menggunakan aplikasi SPSS versi 22. Dari hasil pengujian data, dapat diketahui bahwa nilai $r$ hitung lebih besar dari $r$ tabel yaitu 0,367. Dengan demikian, bahwa seluruh data yang berkaitan pada tiga variabel tersebut dinyatakan valid. 


\section{Importance Performance Analisis (IPA)}

Melalui metode Importance Performance Analysis (IPA), maka akan ditemukan kesenjangan atau jarak yang dapat dijadikan sebagai tolak ukur keefektifan antara harapan dan kenyataan. Harapan atau kepentingan yang seharusnya diterapkan oleh Badan Wakaf Indonesia akan diselaraskan dengan kenyataan atau realita yang diperoleh berdasarkan uraian responden atau nazhir pada kuesioner. Dengan demikian, melalui skor kesenjangan yang diperoleh tersebut, peneliti dapat menarik kesimpulan apakah indikator-indikator yang diperlukan telah efektif dilaksanakan atau belum dapat dilaksanakan.

Indikator-indikator dapat dinyatakan efektif apabila kenyataan (b1) > harapan (a1). Sebaliknya, apabila harapan (a1) > kenyataan (b1), maka pelaksanaan indikator-indikator tersebut belum efektif. Namun jika kesenjangan antara harapan (a1) dan kenyataan (b1) 0 maka indikatorindikator dapat dianggap telah terlaksana. Hasil analisis IPA pada setiap variabel dalam efektivitas pengelolaan wakaf tunai di Badan Wakaf Indonesia dijelaskan sebagai berikut:

\section{Profesionalisme Nazhir}

Profesionalisme nadzir dalam mengelola wakaf di BWI menjadi salah satu hal yang dapat menunjang dalam pengelolaan wakaf, karena nadzir menerima dana titipan umat yang harus digunakan untuk kesejahteraan umat kembali. Adapun variabel profesionalisme nadzir terdapat 5 indikator, yaitu kriteria nazhir terpenuhi, kreativitas nazhir tinggi, pelatihanpelatihan nazhir, dan profesi lain nazhir.

Dari hasil penelitian diketahui bahwa terdapat antara kenyataan dan kepentingan 1. Gap antara kenyataan dan kepentingan menunjukkan hasil positif, artinya bahwa indikator kriteria nazhir pada BWI telah terpenuhi dengan baik dan sesuia dengan harapan.

Indikator kedua dari variabel profesionalisme nazhir yaitu kreativitas nazhir. Hasil analisis gap antara kenyataaan dan kepentingan sebesar -0,93. Hal ini menunjukkan bahwa kreativitas nazhir yang terdapat pada BWI belum tinggi. Karena bernilai negatif, sehingga BWI membutuhkan nazhir-nazhir yang memiliki kreativitas yang sangat tinggi.

Indikator ketiga yang digunakan dalam variabel profesionalisme nazhir adalah pelatihan-pelatihan yang dilaksanakan BWI terhadap nazhir. Berdasarkan hasil yang diperoleh dari responden diketahui bahwa gap yang terjadi antara kenyataan dan kepentingan yaitu -0,963. Hal ini menunjukkan bahwa pelatihan-pelatihan pengelolaan wakaf oleh nazhir masih belum sesuai dengan yang diharapkan.

Indikator terakhir dari variabel profesionalisme nazhir adalah profesi lain yang dilakukan nazhir. Dari hasil analisis, terdapat gap antara kepentingan dan kenyataan dari pernyataan profesi lain yang dimiliki nazhir sebesar 1,5. Nilai tersebut menggambarkan bahwa masih banyak profesi lain yang dimiliki nazhir selain menjadi pengurus wakaf. Hal ini akan berakibat nazhir tidak dapat bekerja secara profesional, karena nazhir tidak terfokus pada satu pekerjaan.

\section{Program Terlaksana Secara Optimal}

Variabel program terlaksana secara optimal ditentukan oleh 8 indikator, yaitu strategi fundraising, target fundraising, pelayanan donasi wakaf uang, administrasi wakaf, investasi wakaf tunai pada sektor keuangan, investasi wakaf tunai pada sektor riil, penyaluran wakaf tunai pada sektor sosial, dan penggantian program kurang produktif. 
Strategi fundraising yang diimplementasikan oleh BWI adalah melakukan kerjasama dengan pihak-pihak tertentu seperti Badan Amil Zakat Nasional, rekening nasabah Bank Syariah Mandiri, BNI Syariah, dan bank-bank syariah lainnya yang ditunjuk sebagai Lembaga Penerima Wakaf Uang (LKS-PWU). Dari hasil kuesioner anatara kepeningan dan kenyataan terlihat adanya gap sebesar 0.237. hal ini menunjukkan bahwa strategi fundraising BWI masih jauh dari harapan.

Indikator kedua dari variabel program terlaksana secara optimal adalah target fundraising. Target fundraising tidak hanya dibutuhkan untuk menambah jumlah besaran wakaf, namun juga dapat diterapkan untuk menambah pengetahuan masyarakat mengenai keberadaan wakaf tunai. Sehingga akan memotivasi masyarakat untuk melakukan wakaf tunai. Berdasarkan hasil dari kuesioner terdapat gap sebesar -1.403. hal ini memberikan gambaran bahwa target fundraising yang dilakukan para nazhir masih jauh dari harapan. Penyebabnya karena nazhir memberikan persepsi bahwa wakaf merupakan bagian dari shadaqah yang tidak wajib seperti zakat, sehingga dalam pelaksanaan fundraisingnya hanya secara sukarela.

Pelayanan donasi wakaf melalui berbagai fitur menjadi salah satu indikator dalam program BWI agar berjalan optimal. Dari hasil kuesioner untuk indikator tersebut terdapat gap sebesar 0,1. Hal ini menunjukkan bahwa indikator ini terlaksana dengan baik dan sesuai dengan harapan.

Indikator lain dari variabel program secara optimal adalah adminsitrasi wakaf. Berdasarkan hasil kuesioner yang telah dilakukan antara kepentingan dan kenyataan pernyataan tersebut terdapat gap sebesar -0.1. gap ini menunjukkan bahwa pada kenyataannya administrasi ini telah dilaksanakan dengan baik. Namun, belum diketahui mengenai ketransparan pencatatan dana wakaf tersebut.

Investasi wakaf tunai pada sektor keuangan menjadi indikator dalam program BWI. Dari hasil analisis gap antara kenyataan dan kepentingan indikator tersebut diperoleh sebesar -1.067. hal ini menunjukkan bahwa investasi dana wakaf tunai pada sektor-sektor keuangan belum dilaksanakan sebagaimana yang telah diharapkan.

Indikator dari variabel program adalah investasi wakaf tunai pada sektor riil. Dari hasil kuesioner terlihat bahawa gap anatar kenyataan dan kepentingan sebesar -1.7. hal ini berart bahwa wakaf tunai pada sektor-sektor riil belum dilaksanakan sebagaimana yang telah diharapkan.

Indikator lain dari variabel program BWI yang berjalan optimal adalah penyaluran wakaf tunai pada sektor sosial. Dari hasil analisis gap terlihat bahwa gap yang terjadi sebesar 1 . Ini artinya bahwa pada kenyataannya dana wakaf yang diperoleh lebih banyak disalurkan kepada sektor sosial.

Indikator terakhir dari variabel program ini adalah penggantian program kurang produktif. Dari hasil kuesioer mengenai pernyataan ini terjadi gap sebesar -1.566 . hal ini menunjukkan bahwa pernyataan ini masih masih jauh dari harapan.

3. Keuntungan Investasi Dana Wakaf Tunai

Adapun variabel keuntungan investasi dana wakaf tunia terdapat 7 indikator, yaitu keuntungan investasi, keuntungan investasi disalurkan pada yayasan (sektor sosial), keuntungan investasi disalurkan pada sektor riil, ketransparan pengelolaan, ketransparan pengelolaan menambah kepercayaan wakif untuk berwakaf secara 
terus menerus, ketransparan pengelolaan dapat memotivasi masyarakat, dan ketransparan pengelolaan meningkatkan perolehan wakaf.

Pada penelitian ini, keuntungan investasi dari dana wakaf tunai antara kepentingan dan kenyataan memiliki gap sebesar 0. Ini artinya bahwa keuntungan dana wakaf ini bersifat seimbang.

Indikator kedua dari variabel keuntungan investasi adalah keuntungan investasi disalurkan pada yayasan (sektor sosial). Dari hasil antara kenyataan dan kepentingan terlihat gap sebesar 0,3. Hal ini berarti bahwa keuntungan yang diperoleh dari dana wakaf lebih banyak diinvestasikan pada sektor sosial.

Indikator ketiga dari variabel keuntungan dana wakaf adalah keuntungan investasi yang disalurkan pada sektor riil. Hasil kuesioner menunjukkan bahwa anatar kenyataan dan kepentingan terdapat gap sebesar -2,1. Hal ini berarti bahwa keuntungan investasi dana wakaf tidak banyak yang disalurkan pada sektor riil, karena masih jauh dari harapan nazhir.

Indikator keempat dari variabel keuntungan dana wakaf yaitu ketransparan pengelolaan wakaf. Berdasarkan hasil penelitian, terdapat gap anatara kepentingan dan kenyataan sebesar -2,337. nilai ini menunjukkan bahwa pernyataan inimasih jauh memenuhi harapan responden.

Indikator kelima adalah ketransparan pengelolaan menambah kepercayaan wakif untuk berwakaf secara terus menerus. Dari pernyataan ini terdapat hasil penelitian anatara kepentingan dan kenyataan yang memiliki gap sebesar -0,9. Hal ini menunjukkan bahwa pernyataan ini belum sepenuhnya memenuhi harapan responden. $\begin{array}{cccr}\text { Indikator } & \text { keenam } \quad \begin{array}{c}\text { dari } \\ \text { veuntungan }\end{array} \text { dana } & \text { wakaf } & \text { adalah } \\ \text { ketransparan } & \text { pengelolaan } & \text { dapat }\end{array}$ memotivasi masyarakat. Berdasarkan penelitian ini menunjukkan bahwa gap antara pentingan dan kenyataan sebesar 0,7 . Hal ini berarti bahwa variabel ini masih belum memenuhi harapan responden.

Indikator terakhir adalah ketransparan pengelolaan meningkatkan perolehan wakaf. Berdasarkan hasil penelitian menunjukkan bahwa gap antara kepentingan dan kenyataan sebesar -0,4. ini artinya bahwa indikator tersebut masih belum sesuai dengan yang diharapkan.

Berdasarkan perhitungan dari nilai-nilai performance diketahui bahwa rata-ratanya sebesar 2,79. Nilai tersebut akan digunakan sebagai batas kuadran dalam analisis IPA pada sumbu X. Sedangkan rata-rata tingkat kenyataan berdasarkan perhitungan adalah 3,36. Nilai tersebut akan dijadikan sebagai batas kuadran IPA pada sumbu Y. Analisis IPA dapat dilihat pada gambar berikut ini:

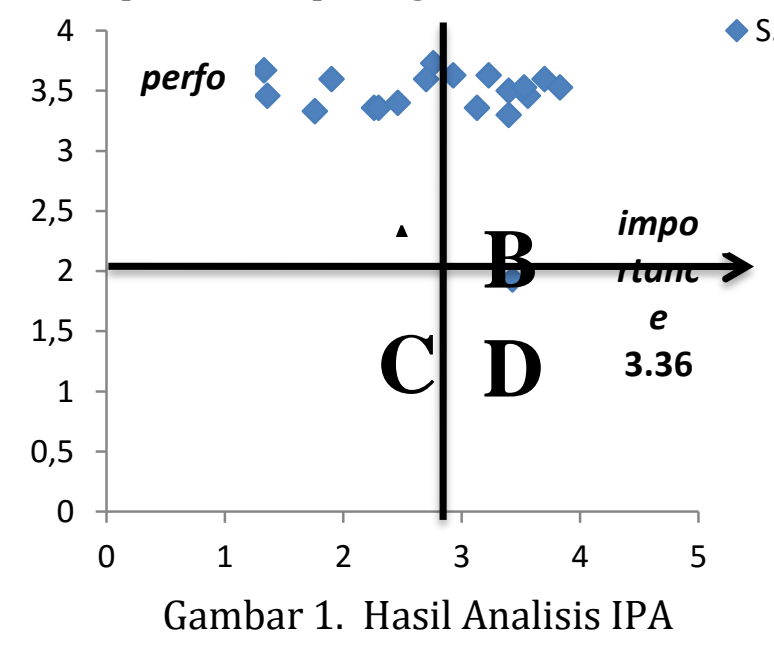

Berdasarkan pada diagram di atas, terdapat titik-titik yang tersebar pada empat kuadran yang dapat diuraikan sebagai berikut:

Kuadran A: Pada kuadran ini, terdapat 9 indikator penting dan sangat berpengaruh terhadap efektivitas pengelolaan wakaf 
tunai yang belum dapat dilaksanakan oleh Badan Wakaf Indonesia, yaitu: (2) nazhir memiliki tingkat kreativitas yang tinggi, (3) adanya pelatihan-pelatihan pengelolaan wakaf oleh nazhir, (6) adanya target dalam melakukan fundraising, (9) investasi wakaf tunai terhadap sektor keuangan sesuai dengan instrumen syariah, (10) investasi dana wakaf tunai pada sektor-sektor riil, (12) adanya penggantian program yang kurang produktif, (15) memproduktifkan kembali keuntungan investasi wakaf tunai pada sektor financial atau sektor riil, (16) ketransparanan pengelolaan wakaf tunai, mulai dari input, proses, sampai kepada output, (17) kepercayaan wakif terhadap pengelolaan wakaf di Badan Wakaf Indonesia. Dengan demikian, Badan Wakaf Indonesia dapat meningkatkan kinerjanya agar empat indikator potensial tersebut dapat terlaksana dengan baik.

Kuadran B: Pada kuadran ini, terdapat 9 indikator penting yang telah dilaksanakan oleh Badan Wakaf Indonesia yaitu nazhir memenuhi empat kriteria shiddiq, amanah, tabligh dan fathanah; (5) adanya strategi-strategi fundraising yang diimplementasikan oleh Badan Wakaf Indonesia; (7) adanya pelayanan donasi wakaf tunai melalui berbagai fitur; (8) adanya administrasi atau pencatatan terhadap wakaf uang; (11) penyaluran dana wakaf tunai pada sektor-sektor riil; (13) adanya tingkat keuntungan investasi wakaf tunai; (14) penyaluran keuntungan investasi wakaf tunai pada sektor sosial atau yayasan; (18) tumbuhnya motivasi masyarakat untuk berwakaf; (19) meningkatnya pertumbuhan wakaf tunai di Badan Wakaf Indonesia. Dengan demikian, Badan Wakaf Indonesia harus mempertahankan indikator-indikator yang telah terlaksana, sehingga akan memicu terlaksananya indikator yang terdapat di kuadran A.

Kuadran C: Pada kuadran ini tidak terdapat titik indikator. Sehingga tidak terdapat indikator yang dianggap tidak berpengaruh secara signifikan terhadap keefektivan pengelolaan wakaf tunai di Badan Wakaf Indonesia.

Kuadran D: Pada kuadran ini, terdapat satu titik indikator yaitu (1) adanya profesi lain yang dimiliki oleh nazhir. Indikator tersebut dianggap tidak terlalu penting namun dapat mempengaruhi tingkat kinerja individu sebagai nazhir.

Berdasarkan perhitungan yang telah dilakukan, dapat diketahui nilai Customer Satisfaction Index (CSI) adalah 54\%. Dengan demikian, Badan Wakaf Indonesia disimpulkan telah memiliki potensi untuk mengelola wakaf secara efektif dan sebagian indikator tersebut telah dilaksanakan. Kesimpulan tersebut dapat didasarkan pada tabel kriteria Customer Satisfaction Index (CSI), bahwa persentase yang berada diantara 50,01\% - 75,01\%, yaitu dari ketiga indikator yang diteliti, Badan Wakaf Indonesia secara rata-rata telah melaksanakan sebagian dari indikator tersebut. Namun Badan Wakaf Indonesia belum melaksanakan program utama sebagai indikator prioritas efektivitas pengelolaan wakaf secara produktif.

\section{KESIMPULAN DAN IMPLIKASI}

Berdasarkan telah dilaksanakannya penelitian dengan judul efektivitas pengelolaan wakaf tunai di Badan Wakaf Indonesia, maka kesimpulan yang dapat diperoleh adalah:

1. Pengelolaan wakaf tunai di Badan Wakaf Indonesia cenderung belum mengarah kepada pengelolaan secara produktif. Sehingga manfaat dari peranan wakaf sebagai pemberdayaan ekonomi belum 
dapat dirasakan oleh masyarakat secara luas.

2. Pengelolaan wakaf tunai di Badan Wakaf Indonesia memiliki potensi untuk mengelola wakaf secara efektif. Pernyataan tersebut dilihat dari hasil analisis yang dilakukan pada metode Customer Satisfaction Index (CSI), dapat disimpulkan bahwa keefektifan pengelolaan wakaf tunai di Badan Wakaf Indonesia mencapai persentase 54\%.

\section{DAFTAR PUSTAKA}

Administrator, 2007. www.bwi.net.

Fanani, Muhyar. Mei 2011. Walisongo: Volume 19, Nomor 1.

Hermawan, wawan. 2014. Jurnal Pendidikan Agama Islam-Ta'lim: Volume 12, Nomor 2.

Hidayanto, Fajar. 2009. Mukaddimah. Volume XV, Nomor 26.

Juliandi, azuar. Irfan. Manurung, Saprinal. 2014. Metodologi penelitian bisnis konsep dan aplikasi. Medan: UMSU PRESS.

Kementerian Agama RI. 2012. Direktorat Jenderal Bimbingan Masyarakat Islam. Direktorat Pemberdayaan Wakaf.

Republika, Indonesia. 2004. UndangUndang Wakaf. Jakarta: Sekretariat Negara.

Rozalinda. 2015. Manajemen Wakaf Produktif. Jakarta: RajaGrafindo Persada.

Sugiyono, 2009. Metode Penelitian Kuantitatif Kualitatif dan R\&D, Bandung: Alfabeta.

Sugiyono. 2013. Metodologi penelitian kombinasi. Bandung: Alfabeta.

Silaningsih, Endang. Gemina, Dwi. 2015. Seminar Nasional Hasil-Hasil Penelitian dan Pengabdian LPPM Universitas Muhammadiyah Purwokerto. ISBN: 978602-4930-3-8.
Umar, Husen. 2003. Metode riset bisnis. Jakarta: Gramedia pustaka utama. 